are bacteriostatic against many Gram-positive bacteria, they inactivate or inhibit some viruses, and their activity is not reduced by tissue fluids or pus. They are used for the treatment of contaminated or suppurative wounds, and have been used in strengths ranging from $0 \cdot 1-0.3 \%$ for the treatment of local infections of the ear, mouth, and throat. Euflavine, which has properties similar to the other acridine derivatives, used in a solution of $1 / 1,000$ is non-irritant and an effective spermicidal. During injection of the solution down each vas most patients experience a sensation in the posterior urethra which many describe as a feeling of wanting to void. A few found this uncomfortable but most made no comment unless asked. The sensation could be reduced and virtually abolished by slow injection of the solution. On voiding after operation the urine is yellow on the first two or three occasions, and the semen is similarly discoloured.

One patient developed haematuria five days after operation. A heavy growth of Escherichia coli was cultured in his urine and it was assumed that the haematuria was a result of this infection.
The infection responded to a course of chemotherapy and there was no recurrence of the bleeding.

Craft and McQueen (1972), in describing the effect of irrigation of the vas on postvasectomy semen counts, suggested that irrigation with a spermicidal preparation might result in a local inflammatory reaction in the seminal vesicles or prostate. This has not been the experience in this series, and the evidence suggests that euflavine used in a $1 / 1,000$ solution has a complete spermicidal action without any irritant side effects. In the light of this experience the method is now used routinely in all vasectomy operations carried out for primary sterilization and it is not considered necessary to examine semen specimens after the procedure to confirm either non-motility of the sperms or azoospermia.

\section{References}

Craft, I., and McQueen, J. (1972). Lancet, 1, 515. von Friesen, B. (1971). Lancet, 1, 598.

\title{
Trial of Chloramphenicol for Meningitis in Northern Savanna of Africa
}

\author{
H. C. WHITTLE, N. McD. DAVIDSON, B. M. GREENWOOD, D. A. WARRELL, A. TOMKINS, \\ P. TUGWELL, A. ZALIN, A. D. M. BRYCESON, E. H. O. PARRY, M. BRUETON, M. DUGGAN, \\ A. D. RAJKOVIĆ
}

British Medical fournal, 1973, 3, 379-381

\section{Summary}

In a controlled trial chloramphenicol proved as effective and much cheaper than penicillin for the treatment of group $A$ meningococcal meningitis in Zaria, Nigeria. A short course of five days cured most patients. Adults and older children were soon able to take chloramphenicol by mouth, which reduced the cost and simplified treatment.

It is suggested that chloramphenicol is a suitable alternative to sulphonamides for the treatment of meningococcal meningitis in those parts of Africa where the organism is sulphonamide-resistant.
Department of Medicine, Ahmadu Bello University, Zaria

H. C. WHITTLE, M.B., M.R.C.P., Lecturer

N. McD. DAVIDSON, B.M., M.R.C.P., Lecturer

B. M. GREENWOOD, M.D., M.R.c.P., Senior Lecturer

D. A. WARRELL, D.M., M.R.C.P., Senior Lecturer

A. TOMKINS, M.B., M.R.C.P., Senior Registrar

P. TUGWELL, M.B., M.R.C.P., Registrar

A. ZALIN, M.B., M.R.C.P., Registrar

A. D. M. BRYCESON, M.D., P.R.C.P., Senior Lecturer

E. H. O. PARRY, M.D., F.R.C.P., Professor

Department of Paediatrics, Ahmadu Bello University, Zaria M. BRUETON, M.R.C.P., D.C.H., Senior Registrar M. DUGGAN, M.R.C.P., D.C.H., Senior Lecturer

Department of Microbiology, Ahmadu Bello University, Zaria A. D. RAJKOVIĆ, M.D., Professor

\section{Introduction}

Every year about 25,000 cases of meningococcal meningitis are reported in epidemics which sweep across the northern savanna of Africa in the dry season (Lapeyssonnie, 1963). In this region long-acting sulphonamides, often given as a single intramuscular dose, have been proved to be a cheap and effective treatment, reducing mortality to about $10-15 \%$ (Lapeyssonnie, 1963). The group A meningococcus, however, which is responsible for these epidemics, has now become resistant to sulphonamides in parts of Africa. In Morocco $90 \%$ of strains isolated from an outbreak were insensitive to sulphadiazine at $10 \mathrm{mg} / \mathrm{l}$. (Sanborn, 1969), in Chad $70 \%$ of strains were resistant to this concentration (Lefèvre et al., 1969), and in Zaria, Nigeria, the figure is $30 \%$ (Sanborn et al., 1973).

An alternative treatment is large and frequent doses of intramuscular penicillin, which has been given to patients with meningococcal meningitis at the Ahmadu Bello University Hospital, Zaria. Though results have been very satisfactory this treatment has not been used elsewhere in the savanna, probably because it is expensive and difficult to administer.

Chloramphenicol is known to be a satisfactory treatment for meningococcal meningitis (McCrumb et al., 1951). Resistant strains seldom develop (Parker et al., 1955; Eickhoff and Finland, 1965) and oral treatment, which is much cheaper than intramuscular penicillin, is also effective (Dean et al., 1953). In Africa chloramphenicol in combination with long-acting sulphonamides (Lefèvre et al., 1969) or with penicillin (Girgis et al., 1972) has been used to treat meningococcal meningitis but its effects alone are not known.

In Zaria, which is in the northern savanna, we have tried chloramphenicol against penicillin in the treatment of meningococcal meningitis to compare their effectiveness and cost when used under local hospital conditions with the aim of 
deciding on a cheap and effective regimen suitable for use in the field by dispensers.

\section{Present Trial}

\section{PATIENTS}

All patients over one year of age with acute untreated meningitis who attended the Ahmadu Bello University Hospital from 1 February to 31 April 1972 were entered into the trial. Those who had received more than 24 hours of antibiotic treatment before admission were not considered. Nineteen patients were later withdrawn. Ten of these had pneumococcal meningitis, eight were wrongly diagnosed as meningitis, and in one the cause of the meningitis was unknown. Thus 123 patients with group A meningococcal meningitis were finally included in the trial. In 79 Neisseria meningitidis was cultured from the C.S.F., in 26 meningococcal antigen was detected in the C.S.F., and in 18 the diagnosis of meningococcal infection was made by a haemagglutination test on paired sera.

\section{DESIGN}

On admission patients were placed in one of the following age groups: 10 years and over, 5-9 years, and 1-4 years. Those within each group were allocated at random to treatment with chloramphenicol or penicillin by numbered sealed envelopes containing the treatment schedules. The schedules and the resultant mean dosages are shown below. For chloramphenicol these dosages relate to the oral preparations and not to the succinate, which was given at a $25 \%$ higher dosage

Chloramphenicol.-Age 10 and over: chloramphenicol succinate $1 \mathrm{~g}$ I.M. initial dose then $1 \mathrm{~g}$ I.M. six-hourly or chloramphenicol capsules $750 \mathrm{mg}$ six-hourly. Mean dosage $80 \pm 24 \mathrm{mg} / \mathrm{kg} / 24 \mathrm{hr}$. Age $5-9$ years: chloramphenicol succinate $625 \mathrm{mg}$ I.M. initial dose then $625 \mathrm{mg}$ I.M. six-hourly or $15 \mathrm{ml}$ chloramphenicol palmitate ( $=500 \mathrm{mg}$ chloramphenicol) six-hourly. Mean dosage $104 \pm 31 \mathrm{mg} / \mathrm{kg} / 24 \mathrm{hr}$. Age 1-4 years: chloramphenicol succinate $310 \mathrm{mg}$ I.M. initial dose then $310 \mathrm{mg}$ I.M. six-hourly or $7.5 \mathrm{ml}$ chloramphenicol palmitate $(=250 \mathrm{mg}$ chloramphenicol) six-hourly. Mean dosage $102 \pm 25 \mathrm{mg} / \mathrm{kg} /$ $24 \mathrm{hr}$.

Crystalline Penicillin.-Age 10 and over: 6 megaunits I.M. initial dose then 3 megaunits I.M. six-hourly. Mean doage $343 \pm 107 \mathrm{IU} / \mathrm{kg} / 24 \mathrm{hr}$. Age 5-9 years: 4 megaunits I.M. initial dose then 2 megaunits I.M. six-hourly. Mean dosage $498 \pm 123 \mathrm{IU} / \mathrm{kg} / 24 \mathrm{hr}$. Age 1-4 years: 2 megaunits I.M. initial dose then 1 megaunit I.M. six-hourly. Mean dosage $365 \pm \mathrm{IU} / \mathrm{kg} / 24 \mathrm{hr}$.

The antibiotics were those used routinely in our hospital and no special price reduction was obtained for the trial. They were bought locally and were of B.P. quality, the same batches of each preparation being used throughout the trial. The prices of each, expressed in sterling, as obtained in bulk for hospital use were as follows: benzlypenicillin injection (B.P.) 2.14p/megaunit (Société Parisienne, D'Expansion Chimique, France); chloramphenicol succinate injec- tion (B.P.) 7.28p/g (E.G.Y.T. Pharmaceutical Works, Hungary); chloramphenicol capsules (B.P.) $1.86 \mathrm{p} / \mathrm{g}$ (Biode Pharmaceutical Industries, Nigeria); syrup of chloramphenicol palmitate $4 \cdot 26 \mathrm{p} / \mathrm{g}$ (United Works of Pharmaceutical and Dietetic Products, Hungary).

A minimum of 21 doses (including the initial dose) was set for each treatment regimen. It was left to the physician in charge to decide when chloramphenicol could be given by mouth, whether treatment beyond a total of 21 doses was necessary, and whether to change treatment to the other antibiotic. Such a change was made only if after 48 hours of treatment the conscious level had not improved or if new signs of neurological damage (such as fits or hemiplegia) appeared.

Treatment was considered to have failed if the patient died, if the treatment had to be changed, or if the patient still had severe neurological damage on the fifth day of treatment.

\section{METHODS}

Clinical.-The body temperature was taken rectally twice daily and the daily mean calculated from these readings. Each patient was seen daily by the same one of four physicians who assessed the level of consciousness and degree of neck stiffness. Patients were discharged as soon as practicable after the completion of treatment and were seen again one week later.

Bacteriological.-C.S.F. was examined by Gram's stain and cultured on chocolate agar in $5 \% \mathrm{CO}_{2}$. After 24 hours of incubation meningococci were identified by morphology, Gram's strain, and the oxidase test.

Immunological.-Antigen was detected in blood and C.S.F. by counter-current immunoelectrophoresis using Difco group A antisera (Greenwood et al., 1971). Haemagglutinating antibodies were determined in acute and convalescent sera by the method of Edwards and Driscoll (1968). A rise in titre of two or more doubling dilutions or an initial titre of one in 64 or greater was accepted as evidence of active infection.

\section{Results}

Of the 123 patients 65 were treated with chloramphenicol and 58 with penicillin. The duration and severity of disease on admission was similar in both groups. The data are summarized in tables I and II. Patients who died or whose treatment was changed have been omitted from these tables.

TABLE I-Number of Doses and Cost of Treatment by Age

\begin{tabular}{|c|c|c|c|c|c|}
\hline \multirow{2}{*}{ Treatment } & \multicolumn{2}{|c|}{ Patients } & \multicolumn{2}{|c|}{ No. of Doses } & \multirow{2}{*}{$\begin{array}{c}\text { Cost of } \\
\text { Treat- } \\
\text { ment } \\
(£ \text { Sterling }\end{array}$} \\
\hline & $\begin{array}{c}\text { Age } \\
\text { Group } \\
\text { (Years) }\end{array}$ & No. & I.M. & Oral & \\
\hline $\begin{array}{l}\text { Chloramphenicol } \\
\text { Penicillin }\end{array}$ & $\begin{array}{l}\geqslant 10 \\
5-9 \\
1-4 \\
\geqslant 10 \\
5-9 \\
1-4\end{array}$ & $\begin{array}{l}26 \\
23 \\
12 \\
21 \\
21 \\
14\end{array}$ & $\begin{array}{r}7 \pm 4 \\
6 \pm 3 \\
12 \pm 10 \\
22 \pm 2 \\
22 \pm 5 \\
22 \pm 4\end{array}$ & $\begin{array}{c}14 \pm 4 \\
15 \pm 4 \\
11 \pm 6 \\
= \\
=\end{array}$ & $\begin{array}{l}0.70 \\
0.61 \\
0.41 \\
1.46 \\
1.02 \\
0.52\end{array}$ \\
\hline
\end{tabular}

I.M. = Intramuscular.

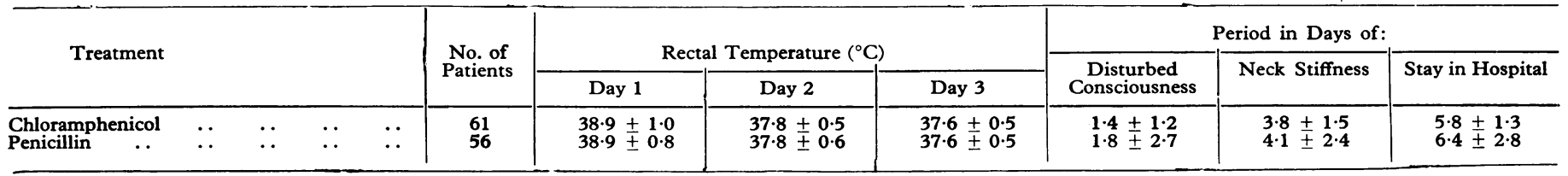


Number of Doses.-This did not differ significantly between the two antibiotics.

Route of Administration.-Children aged 1-4 were given more doses of chloramphenicol intramuscularly than older children.

Cost.-Overall, chloramphenicol cost $45 \%$ less than penicillin.

Response to Treatment.-This did not differ significantly by antibiotic or by age group (table II).

Failures of Treatment.-There were nine with chloramphenicol and 10 with penicillin. Two patients in the chloramphenicol and one in the penicillin group died. Three patients were changed from chloramphenicol to penicillin therapy; one of these died and the other two recovered. One patient who recovered was changed from penicillin to chloramphenicol. At the time of the change the C.S.F. was sterile in three of the patients. In the fourth, a 2-year-old child who was treated with chloramphenicol for 48 hours, $N$. meningitidis was isolated from the C.S.F. This organism was sensitive to chloramphenicol when tested in vitro. Five of those treated with chloramphenicol and eight of those given penicillin still had severe neurological complications on day 5 (table III). This damage was most severe and frequent in the young children.

TABLE III-Details and Prognosis of 13 Patients with Severe Neurological Signs

\begin{tabular}{|c|c|c|c|}
\hline \multirow{2}{*}{ Treatment } & \multirow{2}{*}{$\begin{array}{c}\text { Age } \\
\text { Years }\end{array}$} & \multicolumn{2}{|c|}{ Signs } \\
\hline & & Day 5 & Follow-up \\
\hline Chloramphenicol & $\begin{array}{c}27 \\
6 \\
3 \\
1 \frac{1}{12} \\
15^{\frac{2}{2}} \\
6 \\
5 \\
4 \\
3 \\
3 \frac{1}{2} \\
2 \\
2\end{array}$ & $\begin{array}{l}\text { Fits } \\
\text { Deaf } \\
\text { Unable to sit } \\
\text { Unable to sit } \\
\text { Spastic quadriplegia } \\
\text { Hemiparesis } \\
\text { Unable to sit } \\
\text { Unable to sit } \\
\text { Ataxic deaf } \\
\text { Defective vision } \\
\text { Hemiparesis } \\
\text { Blind } \\
\text { Hemiparesis }\end{array}$ & $\begin{array}{l}\text { Normal } \\
\text { Normal } \\
\text { Walking after six } \\
\text { weeks } \\
\text { Normal } \\
\text { No improvement } \\
\text { Normal } \\
\text { No improvement } \\
\text { Normal } \\
\text { Attaxic deaf } \\
\text { Normal } \\
\text { Improved } \\
\text { Blind } \\
\text { Improved }\end{array}$ \\
\hline
\end{tabular}

Follow-up.-Eighty per cent. of the patients attended the follow-up clinic. No relapses were seen and nine of the patients with severe neurological damage improved remarkably.

\section{Discussion}

Chloramphenicol proved to be as effective as penicillin in the treatment of meningococcal meningitis in both adults and children. Five days of treatment cured most patients; adults and older children were soon able to take the drug by mouth. This saved money because chloramphenicol is cheaper than penicillin. Young children, however, needed more of the drug intramuscularly as they were often uncooperative and refused oral therapy. This group forms only $20 \%$ of cases in the epidemics in the savanna (Lapeyssonnie, 1963), and as the dose is small the overall extra expenditure for the parenteral preparation should not be great.

Both antibiotics were satisfactory as mortality was low and most of those who had severe neurological damage eventually recovered. No relapses and no cases of drug toxicity were seen
The development of sulphonamide-resistant meningococci in the meningitis belt is likely to lead to an increased mortality if this drug remains the only form of therapy. This is the reason why we in Zaria tried chloramphenicol against penicillin instead of a sulphonamide. Effective alternatives such as ampicillin or co-trimoxazole were not considered as they are too expensive for large-scale use in the meningitis belt of Africa.

In this trial dosage was based on age and not on weight in order to simplify treatment and conform to present antibiotic regimes used in the Nigerian field. This inevitably resulted in wide individual variation in the amount given per $\mathrm{kg}$ body weight. The dosage of chloramphenicol succinate was also increased about $25 \%$ over that of oral chloramphenicol in view of a report of the relative ineffectiveness of intramuscular chloramphenicol (Du/Pont et al., 1970). In practice, however, it has yet to be shown that chloramphenicol by the intramuscular route is less effective than the other routes in the treatment of meningitis (Bulos, 1972; Nelson et al., 1972). The dosage of penicillin (250,000-500,000 IU/ $24 \mathrm{hr}$ ) is that recommended by many authorities working in Africa (Sorensen, 1969; Girgis et al., 1972; Mpairwe et al., 1972). We have been reluctant to lower this, as in the past when forced to use smaller doses we have thought the drug to be less effective.

Chloramphenicol has advantages which make it suitable for use in the field, where most patients in the epidemics of meningitis are treated. A short course is effective and it can be given by mouth, which cuts costs and simplifies treatment. Also it is effective against both Hemophilus influenzae (Nelson et al., 1972) and Diplococcus pneumoniae meningitis (Parker et al., 1955), which is important as a precise bacteriological diagnosis is seldom made in the field. We believe that these factors more than offset the danger that chloramphenicol may cause aplastic anaemia in a very few patients (Wallerstein et al., 1969).

We wish to thank Professor Umaru Shehu, director of the Institute of Health, for his help and encouragement. Helen Pope, Jill Boler, and Barbara Hudson provided excellent technical help.

\section{References}

Bulos, N. K. (1972). Fournal of Pediatrics, 81, 416.

Deane, G. E., Furman, J. E., Bentz, A. R., and Woodward, T. E. (1953). Pediatrics, $2,368$.

DuPont, H. L., Hornick, R. B., Weiss, C. F., Snyder, M. J., and Woodward, T. E. (1970). New England Fournal of Medicine, 282, 53.

Edwards, E. A., and Driscoll, W. S. (1968). Proceedings of the Society for Experimental Biology and Medicine, 126, 976.

Eickhoff, T. C., and Finland, M. (1965). New England fournal of Medicine, 272, 395.

Girgis, N. I., et al. (1972). Fournal of Tropical Medicine and Hygiene, 73, 154.
Greenwood, B. M., Whittle, H. C., and Dominic-Rajkovic, O. (1971). Lancet, 2, 519.

Lapeyssonnie, L. (1963). Bulletin of the World Health Organization, 28,

supplement.
Lefévre, M., Sirol, J., Vandekerkove, M., and Faucon, R. (1969). Bulletin of the World Health Organization, 40,331.

McCrumb, F. R., et al. (1951). American fournal of Medicine, 10, 696.

Mpairwe, Y., Laurance, B. M., and Kanyerezi, B. R. (1972). In Medicine in a Tropical Environment, ed. A. G. Shaper, J. W. Kibukamusoke, and M. S. R. Hutt. London, British Medical Ássociation.

Nelson, K. E., Levin, S., Spies, H. W., and Lepper, M. H. (1972). fournal

of Infectious Diseases, 125, 549.
Parker, R. T., Snyder, M. J., Liu, R. S. J., Looper, J. W., and Woodward, T. E. (1955). Antibiotic Medicine, 1, 192.

Sanborn, W. R. (1969). Fournal of the Egyptian Public Health Association, 44, 356.

Sanborn, W. R., et al. (1973). Unpublished.

Sorenson, K. (1969). Fournal of the Egyptian Public Health Association, 44 408.

Wallerstein, R. O., Condit, P. K., Kasper, L. K., Brown, J. W., and Morrison, F. R. (1969). Fournal of the American Medical Association, 208, 2045. 